\title{
EFFECT OF HYDROXYETHYL STARCH 200/0.5 ON VON WILLEBRAND FACTOR SERUM LEVEL AND ACTIVATED PARTIAL THROMBOPLASTIN TIME (APTT)
}

\author{
Sarah Puspita Atmaja ${ }^{1}$, Junaidi Khotib ${ }^{1}$, Eddy Rahardjo ${ }^{2}$, Dewi Wara Shinta ${ }^{1}$, Mahardian Rahmadi ${ }^{1}$, \\ Budi Suprapti ${ }^{1}$ \\ ${ }^{1}$ Department of Clinical Pharmacy, Faculty of Pharmacy, Airlangga University \\ ${ }^{2}$ Department of Anesthesiology and Reanimation, Faculty of Pharmacy, Airlangga University
}

\begin{abstract}
ABSTRAK
Hydroxyethyl starch (HES) merupakan koloid yang sering digunakan sebagai plasma ekspander selama periode operasi. Beberapa gangguan haemostasis sudah dilaporkan akibat penggunaan HES, namun volume HES yang diberikan lebih dari $20 \mathrm{ml} / \mathrm{kgBB}$. Tujuan penelitian ini adalah untuk mengevaluasi pengaruh Hydroxyethyl starch 200/0,5 dengan dosis kurang dari $20 \mathrm{ml} / \mathrm{kg}$ BB terhadap kadar faktor von Willebrand dan activated partial thromboplastin time. Penelitian dilakukan dengan metode prospektif observasional. Kriteria inklusi penelitian ini adalah pasien yang menjalani operasi elektif yang mendapat HES 200/0,5 selama operasi. Empat puluh enam pasien dibagi menjadi dua kelompok yaitu kelompok pasien yang hanya mendapatkan cairan kristaloid ( $n=23$ pasien) dan HES ( $n=23$ pasien). Koagulasi diperiksa 30 menit setelah insisi dan 60 menit setelah pemberian kritaloid atau koloid. Penurunan yang signifikan pada kadar faktor von Willebrand didapatkan pada kedua kelompok. Didapatkan penurunan dari (mean \pm SE) 97,688 $\pm 15,219 \mathrm{ng} / \mathrm{ml}$ menjadi 31,611 $\pm 10,058 \mathrm{ng} / \mathrm{ml}(\mathrm{p}<0,001)$ pada kelompok kristaloid dan 92,884 $\pm 15,208 \mathrm{ng} / \mathrm{ml}$ menjadi 27,378 $\pm 6,399 \mathrm{ng} / \mathrm{ml}(\mathrm{p}<0,001)$ pada kelompok HES 200. Perubahan signifikan activated partial thromboplastin time hanya

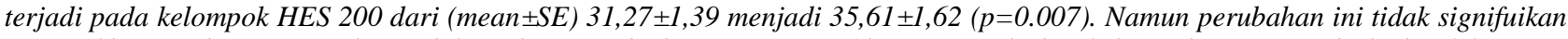
secara klinis. Sebagai simpulan, tidak terdapat perbedaan yang signifikan antara kedua kelompok cairan pada kadar faktor von Willebrand atau APTT. Tidak terdapat pengaruh koagulasi yang memberikan efek klinik yang signifikan pada penggunaan HES 20 $\mathrm{ml} / \mathrm{kg}$ BB selama pasien menjalani operasi elektif. (FMI 2015;51:221-227)
\end{abstract}

Kata kunci: hydroxyethyl starch 200/0,5, kadar faktor von Willebrand factor, activated partial thrombopalstin time

\begin{abstract}
Hydroxyethyl starch (HES) is a colloid administered frequently for intravascular volume expansion during perioperative period. Impairment of haemostasis have been reported during HES administration, but the volume of solution administered was usually higher than $20 \mathrm{ml} . \mathrm{kg}-1$. The objective of this study was to evaluate the effect of Hydroxyethyl starch 200/0.5 dose less than $20 \mathrm{ml} . \mathrm{kg}-1$ on von Willebrand factor serum level and activated partial thromboplastin time. A prospective, observational study was conducted to evaluate von Willebrand factor and activated partial thromboplastin time of patients receiving Hydroxyethyl starch $200 / 0.5$. Inclusion criteria were patients undergoing elective surgery who were going to receive Hydroxyethyl starch 200/0.5 intraoperatively. Fourty six patients were divided into patients receiving crystalloid only group ( $n=23$ patients) and hydroxyethyl starch ( $n=23$ patients). Coagulation variables were assesed 30 minute after insicion and 60 minute after infusion of crystalloid or colloid. Measurement of von Willebrand within each group after crystalloid or HES 200 infusion showed significant decrease, from $($ mean $\pm S E) 97.688 \pm 15.219 \mathrm{ng} / \mathrm{ml}$ to $31.611 \pm 10.058 \mathrm{ng} / \mathrm{ml}(\mathrm{p}<0.001)$ in crystalloid group and $92.884 \pm 15.208 \mathrm{ng} / \mathrm{ml}$ to $27.378 \pm 6.399$ $n g / m l(p<0.001)$ in HES 200 group. Activated partial thromboplastin time change was statistically significant (mean $\pm S E) 31.27 \pm 1.39$ to $35.61 \pm 1.62$ in HES group only $(p=0.007)$, but this change was not clinically significant. In conclusion, there was neither significant difference in von Willebrand serum level nor in activated partial thromboplastin time between the two groups. There was no coagulation influence with clinically significant effect in the use of HES $20 \mathrm{ml} / \mathrm{kg} \mathrm{BW}$ in patients undergoing elective surgery.
\end{abstract} (FMI 2015;51:221-227)

Keywords: hydroxyethyl starch 200/0.5, coagulation impairment, von Willebrand factor serum level, activated partial thrombopalstin time

Correspondence: Sarah Puspita Atmaja, Department of Clinical Pharmacy, Faculty of Pharmacy, Airlangga University, Jalan Dharmawangsa Dalam, Surabaya 60286, Indonesia. Email: sarahpuspita.pharmacist@gmail.com

\section{INTRODUCTION}

Hydroxyethyl starch (HES) is widely used as a plasma substitute in bleeding during surgery. HES is a synthesis of amylopectin with hydroxyethyl substitution by ethylene oxide at position $\mathrm{C} 2$ and $\mathrm{C} 6$ which is able to slow down enzymatic degradation by amylase, thereby extending its intravascular shelf life (Mills 2007, Gan 
2011, Myburgh \& Mythen 2013). To achieve hemodynamic stability, HES requires less volume than $\mathrm{NaCl}$ (Guidet et al 2012).

The influence of HES 200/0.5 use in decreasing levels of von Willebrand factor was observed in healthy volunteers (de Jonge et al 2001). Whereas, study on surgery patients who used HES 200/0.5 during the operation at a dose of $2.104 \pm 622$ showed significant APTT prolongation and decreased levels of von Willebrand factor in the group receiving HES 200/0.5, and that blood loss and the need for blood transfusions were significantly more common in patients using HES 200/0.5 (KozekLangenecker et al 2008).

The effect of HES on blood coagulation function in subjects in Indonesia has not been studied. This study examined the effect of HES on blood coagulation based on HES doses in Dr Soetomo Hospital, which was as much as $10-20 \mathrm{ml} / \mathrm{kg}$ during surgery. This study aimed to evaluate the effect of hydroxyethyl starch as fluid resuscitation in patients who have bleeding during surgery on von Willebrand factor level and activated partial thromboplastin time (APTT).

\section{MATERIALS AND METHODS}

This study used prospective observational design with sample of patients undergoing elective surgery in Gedung Bedah Pusat Terpadu (GBPT), Dr. Soetomo Hospital, Surabaya, and required crystalloid resuscitation therapy as a control group and HES as treatment group included in inclusion and exclusion criteria. The inclusion criteria were age 18-50 years; patients undergoing elective surgery with a maximum bleeding of $20 \% \mathrm{EBV}$ who received crystalloid resuscitation or HES 200/0.5, willing to sign the informed consent, patients with coagulation function (PT <13 APTT <33 seconds), renal or hepatic function (serum creatinine $<1.2 \mathrm{mg} / \mathrm{dL}$, alanine amino transferase $<90 \mathrm{mg} / \mathrm{dl}$, or aspartate amino transferase $<70 \mathrm{mg} / \mathrm{dl}$ ); and patients with $\mathrm{Hb}>10 \mathrm{~g} / \mathrm{dl}$. Exclusion criteria for the study were patients who received warfarin, heparin or low molecular weight heparin, clopidogrel or for 5 days before surgery, patients receiving oral contraceptives, and long term use of corticosteroids.

Subjects were divided into two groups: crystalloid and HES 200 groups. Both groups received crystalloid as maintenance fluid to overcome the loss of fluids through urine, gastrointestinal and respiratory during operation. The choice of the fluid depends on the bleeding condition of each patient.
Blood samples were taken twice, initial for baseline level, 30 minutes after the incision, and 60 minutes after the fluid was given. Of the samples obtained, the activated partial thromboplastin time (APTT) and von Willebrand factor level was measured using von Willebrand antigen (vWF: ag) with ELISA method of Elabscience.

Data obtained were in the form of means \pm SE. ShapiroWilk test was used to test data normality. Comparative test for pre- and post von Willebrand factor levels and APTT in each group was done using paired t-test when the distribution was normal, and Wilcoxon test if the distribution was not normal. As for comparing the value of the parameter in the patients receiving HES and patients who did not use HES (controls) we used ANCOVA with covariat bleeding (\% EBV) if the data were homogeneous and linear regression test if the data were not homogeneous.

To show the effect of plasma dilution by HES or crystalloid, we made the calculation according to the formula $\mathrm{D}=\mathrm{Hb} / \mathrm{Hb} 0 \times(1-\mathrm{Ht} 0) /(1-\mathrm{Ht})$, in which $\mathrm{D}$ : dilution factor; $\mathrm{HbO}, \mathrm{Ht} 0$ : hemoglobin and hematocrit concentration prior to infusion fluids; and $\mathrm{Hb}, \mathrm{Ht}$ : hemoglobin and hematocrit concentrations after fluid infusion. Subsequently, the concentration of von Willebrand factor in plasma after dilution was calculated using formula $\mathrm{C}=\mathrm{C} 0 \times \mathrm{D}$, with $\mathrm{C} 0$ : concentration before dilution; $\mathrm{C}$ : concentration after dilution; $\mathrm{D}$ : dilution factor. Statistical calculations of independent ttest was used to compare the calculation levels of von Willebrand factor from baseline and after fluid infusion in each group.

\section{RESULTS}

A total of 46 patients involved in this study were divided into two groups, the group of patients who only received crystalloid and a group of patients who received crystalloid and HES 200. From the data on patients characteristics involved in this study and the amount of resuscitation fluid provided during the observation, there were no significant differences between the two groups (Table 1 and Table 3). However, there was significant difference as for the bleeding volume occured during surgery between the two groups (Table 2). vWF levels in blood decreased significantly in both groups $(\mathrm{p}<0.001)$. However, when compared the difference of vWF:ag between both groups, there was no significant difference $(p=0.486)$. When compared with calculations using dilution factor (Table 5), the decrease of vWF in each group showed significant difference $(\mathrm{p}<0.001)$ (Figure 1). 
Table 1. Characteristics of patients involved in the study

\begin{tabular}{lccc}
\hline \multicolumn{1}{c}{ Parameters } & $\begin{array}{c}\text { Crystalloid } \\
(\mathrm{n}=23)\end{array}$ & $\begin{array}{c}\text { HES 200 } \\
(\mathrm{n}=23)\end{array}$ & $\mathrm{P}$ values \\
\hline Ages (years) & $43.39 \pm 11.54$ & $46.60 \pm 9.12$ & $\mathrm{p}=0.061$ \\
Creatinin serum $(\mathrm{mg} / \mathrm{dl})$ & $0.72 \pm 0.19$ & $0.78 \pm 0.20$ & $\mathrm{p}=0.350$ \\
APTT $(\mathrm{sec})$ & $29.17 \pm 5.52$ & $27.8 \pm 5.34$ & $\mathrm{p}=0.428$ \\
SGOT $(\mathrm{mg} / \mathrm{dl})$ & $19.21 \pm 10.51$ & $18.85 \pm 13.36$ & $\mathrm{p}=0.925$ \\
SGPT $(\mathrm{mg} / \mathrm{dl})$ & $22.26 \pm 10.15$ & $19.61 \pm 11.08$ & $\mathrm{p}=0.436$ \\
Hb $(\mathrm{g} / \mathrm{dl})$ & $12.5 \pm 1.26$ & $12.09 \pm 1.48$ & $\mathrm{p}=0.309$ \\
\hline
\end{tabular}

Table 2. Total bleeding volume in crystalloid and HES 200 groups during operation

\begin{tabular}{lccc}
\hline & $\begin{array}{c}\text { Crystalloid group } \\
(\text { mean } \pm \text { SD })\end{array}$ & $\begin{array}{c}\text { HES 200 group } \\
(\text { mean } \pm \text { SD })\end{array}$ & P value \\
\cline { 2 - 4 } Bleeding $(\% \mathrm{EBV})$ & $9.04 \pm 4.37$ & $15.77 \pm 5.97$ & $<0.001 * *$ \\
\hline \multicolumn{4}{c}{$* *$ Coagulation studies }
\end{tabular}

Tabel 3. Total fluid received by patients in crystalloid and HES 200 groups

\begin{tabular}{cccc}
\hline & $\begin{array}{c}\text { Crystalloid group } \\
\text { (mean } \pm \text { SE) }\end{array}$ & $\begin{array}{c}\text { HES 200 group } \\
(\text { mean } \pm \text { SE) }\end{array}$ & P value \\
\cline { 2 - 3 } $\begin{array}{c}\text { Total administered } \\
\text { fluid }\end{array}$ & $\begin{array}{c}\text { Crystalloid : } \\
1113.04 \pm 96.490\end{array}$ & $\begin{array}{c}\text { Crystalloid : } \\
1249.13 \pm 79.404\end{array}$ & 0.282 \\
& & HES : 507 $\pm 45.70 \mathrm{ml}$ & \\
\hline
\end{tabular}

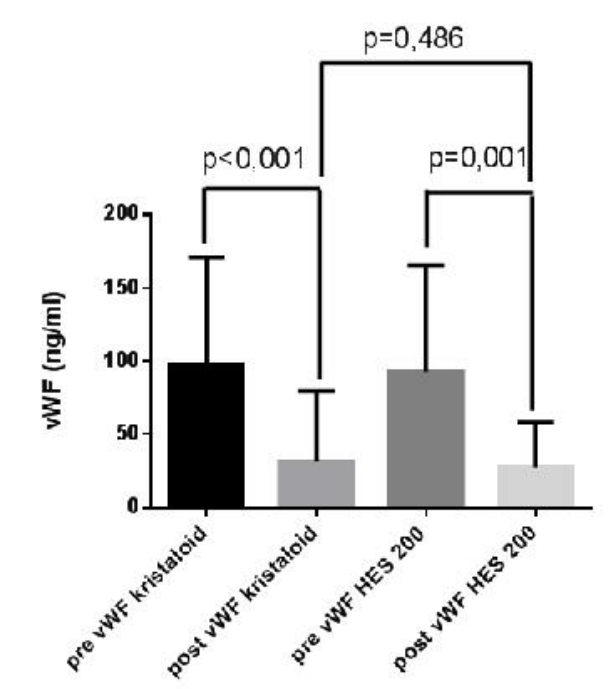

Figure 1. Changes in the levels of von Willebrand factor in crystalloid and HES 200 groups

Table 4. Comparative test pre and post of von Willebrand factor levels in crystalloid and HES 200 groups

\begin{tabular}{cccccc}
\hline Groups & $\mathrm{n}$ & $\begin{array}{c}\text { pre } \\
\text { mean } \pm \text { SE. }\end{array}$ & $\begin{array}{c}\text { post } \\
\text { mean } \pm \text { SE. }\end{array}$ & $\begin{array}{c}\text { Comparison } \\
\text { mean } \pm \text { SE. }\end{array}$ & P value \\
\hline Crystalloid & 23 & $97.688 \pm 15.219$ & $31.611 \pm 10.058$ & $-66.086 \pm 14.677$ & $<0.001^{* *}$ \\
HES 200 & 23 & $92.884 \pm 15.208$ & $27.378 \pm 6.399$ & $-65.934 \pm 13.757$ & $<0.001^{* *}$ \\
\hline **Coagulation
\end{tabular}

**Coagulation studies 
Table 5. Comparation of calculated von Willebrand factor levels and measured von Willebrand factor levels

\begin{tabular}{cccc}
\hline Fluid groups & $\begin{array}{c}\text { Calculated vWF } \\
\text { level } \pm \text { SD }\end{array}$ & $\begin{array}{c}\text { Measured vWF } \\
\text { level } \pm \text { SD }\end{array}$ & P value \\
\hline Crystalloid & $93.97 \pm 7.36$ & $27.37 \pm 3.06$ & $<0.001^{* *}$ \\
HES 200 & $96.72 \pm 7.45$ & $31.61 \pm 4.83$ & $<0.001^{* *}$ \\
\hline
\end{tabular}

***agulation studies

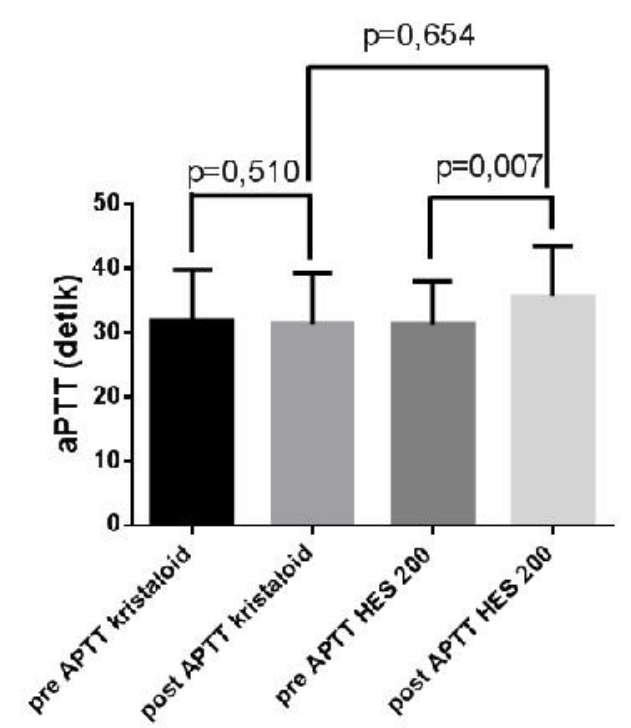

Figure 2. Changes in APTT in crystalloid and HES 200 groups

Table 6. Comparison of pre and post APTT in in crystalloid and HES 200 groups

\begin{tabular}{lccccc}
\hline & $\mathrm{n}$ & $\begin{array}{c}\text { pre } \\
\text { mean } \pm \text { SE }\end{array}$ & $\begin{array}{c}\text { post } \\
\text { mean } \pm \text { SE }\end{array}$ & $\begin{array}{c}\text { Comparison } \\
\text { mean } \pm \text { SE }\end{array}$ & P value \\
\hline Crystalloid & 23 & $31.87 \pm 1.63$ & $31.33 \pm 1.60$ & $0.54 \pm 0.81$ & 0.510 \\
HES 200 & 23 & $31.27 \pm 1.39$ & $35.61 \pm 1.62$ & $4.33 \pm 1.46$ & $0.007 * *$ \\
\hline
\end{tabular}

APTT results in each group showed no significant change (Figure 2), as we also see if we compared the APTT difference between both groups $(\mathrm{p}=0.654)$

\section{DISCUSSION}

The focus of this study was on the effect of HES 200 administration on the alteration of von Willebrand factor level. Statistical analysis (Table 4) revealed that the level of von Willebrand factor either in cristalloid or HES 2000 groups showed significant reduction, with a slight higher mean in cristalloid group compared to that in HES 2000 group $(66.086 \pm 14.677$ vs $65.934 \pm 13.757)$. Characteristics of total bleeding between both groups also showed significant difference (Table 2). In cristal- loid group, the \%EBV was $9.04 \pm 4.37$, while that in HES 2000 group was $15.77 \pm 5.97$. This finding raised question whether such difference in total bleeding may affect difference of von Willbrand factor reduction. Therefore, to compare this difference between patients receiving cristalloid and those receiving HES 2000, we used multivariate analysis with linear regression test. The test revealed no significant difference (Figure 2) between both groups with $\mathrm{p}=0.486$.

The reduction in each group (Table 4) lead to von Willebrand factor level of $31.611 \pm 10.058 \mathrm{ng} / \mathrm{ml}$ in cristallooid group and $27.378 \pm 6.499 \mathrm{ng} / \mathrm{ml}$ in HES 200 group. Sadler (2009) suggested that the reduction of vol Willebrand factor of $30-50 \mathrm{ng} / \mathrm{ml}$ has intermediate bleeding risk. However, this study has limiation since it 
did not evaluate further, whether the reduction of Willebrand factor due to HES 200 administration continues.

Decreased levels of von Willebrand factor in crystalloid and HES 200 groups in this study confirmed previous study by Innerhofer et al (2002) in 60 patients undergoing orthopedic surgery. The study found significant decrease of von Willebrand factor is in Ringer Lactate group $(4801 \pm 1239 \mathrm{ml})$ from $130 \%$ to $121 \%$ and in HES group $200(1242 \pm 315 \mathrm{ml})$ from $128 \%$ to $118 \%$, which was observed before and after surgery. The study did not find difference in significant decrease in von Willebrand factor between Ringer's lactate and HES 200 groups. Declining levels of von Willebrand factor was also found by Muralldhar (2010) in a study of patients undergoing coronary artery bypass. In that study, most significant vWF levels decrease was found after the administration of $7-8 \mathrm{ml} / \mathrm{kg}$ HES 200. However, 24 hours after the operation, von Willebrand factor levels rose again, approaching baseline levels.

In physiological conditions, the elimination of von Willebrand factor is carried out by the liver and spleen. Macrophages are a type of cells that play the most predominant role in two organs in the process of von Willebrand factor elimination. Receptors that have been identified to play a role in mediating vWF factor endocytosis in macrophages is a lipoprotein receptor (LPR1) and Siglec-5. The half-life of von Willebrand factor in circulation is 16 hours. In this study, sampling point after HES 200 administration was 60 minutes. Therefore, the decline of HES 200 in this study was not influenced by vWF factor half-life in blood circulation (Casari et al 2013, Lenting et al 2014).

In this study, von Willebrand factor decrease was not only due to the dilution, as confirmed by calculation of the plasma dilution factor. Results of calculations with dilution factor was compared with post-treatment von Willebrand factor in each fluid group. If the results of the comparative test showed significant difference, it can be concluded that the decrease of von Willebrand factor is not only the result of dilution. From comparative test results (Table 5) using the Mann-Whitney test there were significant differences in each group $(\mathrm{p}=$ 0.000) for crystalloid and HES 200 groups.

Mechanisms that could explain how the influence of hydroxyethyl starch can reduce von Willebrand factor cannot be confirmed. An in vitro study conducted by Collis et al (1994), observing the influence of hydroxyethyl starch on endothelial cells activity in culture, showed that there was inhibition of von Willebrand factor release, which comprised adhesion molecules stored in endothelial cells in group receiving HES. This resulted in significant decreased of von Willebrand factor $(\mathrm{p}=0.01)$ compared to other plasma substitution fluids. This is supported by a study by Ritto et al (2005), who compared the effect of hydroxyethyl starch with gelofusin in patients with abdominal aortic aneurysm repair. Decreased level of von Willebrand factor was obtained in two groups at the beginning before the opening of the aortic clamp abdominal. The reducation indicates acute phase of response proteins in circulation, resulting in increased consumption of vWF factor.

Furthermore, after the clamp was opened vWF factor increased in gelofusin group from $110 \mathrm{U} / \mathrm{dL}$ to 173.5 $\mathrm{U} / \mathrm{dl}$, showing a continued release of vWF by endothelial activation, whereas in the HES group decreased from $96.5 \mathrm{U} / \mathrm{dl}$ to $80.5 \mathrm{U} / \mathrm{dl}$. This indicates that after initial endothelial activation, HES affected the stabilization of effects of endothelium. The finding that improved endothelial stabilization results from HES influence is supported by a study by Boldt et al (2003). This study did not use vWF factor as parameter. Instead, it used adhesion molecules released in the circulation, the endhotelial leukocyte adhesion molecule-1 (ELAM-1) and intercellular adhesion molecule-1 (ICAM-1), that may reflect the activation of endothelial cells. This study found an increase of both adhesion molecules which was higher in crystalloid group compared to that in HES group $(p=0.05)$. This demonstrates that the HES has a stabilizing effect on endothelial cells by stabilizing fragile cell membranes, so that it reduces its activity in releasing of adhesion molecules. However, we are still unable to explain the mechanism of vWF factor reduction in the group of patients receiving crystalloid fluids alone.

In this study, vWF factor reduction in HES group was followed by prolonged APTT time (Table 6) from 31.27 \pm 1.39 to $35.61 \pm 1.62(\mathrm{p}=0.007)$. In crystalloid group von Willebrand factor decreased from $97.688 \pm 15.219$ $\mathrm{ng} / \mathrm{ml}$ to $31.611 \pm 10.058 \mathrm{ng} / \mathrm{ml}$ (Table 4 ), but was not followed by statistically significant changes in APTT (Table 6). Comparative analysis of APTT difference between patients receiving crystalloid solution and those receiving HES 200 was done using ANCOVA statistical test. The result showed no significant differences between both groups with $\mathrm{p}=0.654$ (Figure 2). Other studies in healthy volunteers and in surgery patients by Langeron et al (2001) and de Jonge et al (2001) showed significant prolonged APTT in patients receiving HES 200 fluid. Insignificant APTT alteration in crystalloid and HES 200 groups was also obtained a study by Rutmann et al (2002). Increased APTT in HES group was $4.33 \pm 7.04$ seconds of normal value. Although it is significant statistically, clinically it is not, since clinically pathological increase of APTT is the increase 
as many as 1.5-2.5 times that of control value (Wilson 2008).

Decreased levels of von Willebrand factor in each group, as seen in Fgure 1, shows decreased levels of von Willebrand factor in patients receiving HES 200 fluid. In addition to HES 200, this group also received crystalloid and showed decreased von Willebrand factor that was not significantly different from that of patients who received crystalloid fluids alone. Similarly, APTT alteration (as seen in Figure 2) shows that HES 200 administration in bleeding patients, reaching averagely $15 \%$ EBV with maximum dose of HES 200 of $20 \mathrm{ml} / \mathrm{kg}$, could still be regarded as clinically safe.

Prolonged APTT time in HES 200 use indirectly resulted from decreased $\mathrm{vWF}$ factor. In domain $\mathrm{D}$ of vWF structure, there is the site of blood clotting factor VIII binding, while the factor VIII itslef belongs to intrinsic pathway of blood coagulation. Prolonged APTT time may result from reduced blood clotting factors in the intrinsic pathway, one of which is the factor VIII (Kamal et al 2007, Reininger 2008, Gabali et al 2014). Von Willebrand factor reduction in circulation caused by HES use affects the decrease of factor VIII concentration because vWF has a function to maintain the stability of factor VIII. Bind-ing form of vWF-VIII protects factor VIII from degradation of protein $\mathrm{C}$ (Peyvandi 2011). Therefore, reduced levels of vWF factor in circulation will be followed by decreased levels of factor VIII since a large number of factors VIII being degraded by protein C. A study by Langeron et al (2001) and Innerhofer et al (2002) showed a significant decrease in vWF factor followed by decreased levels of factor VIII in the use of HES 200.

According to Wilson (2008), prolonged APTT is not only caused by decreased levels of factor VIII, but also be affected by the decreased of other factors' levels, the factor I, II, V, IX, X, XI, and XII. Therefore, in this study prolonged APTT in a group of patients receiving HES 200 was not only due to decreased levels of factor VIII as described above, but could also be due to decreased levels of other factors, as has been proved a study by Fenger-Eriksen et al (2009). However, this study did not observe other coagulation factors.

As to the use of crystalloid, there was no change in APTT. This may be explained from in vivo study on hepatobiliary surgery patients conducted by $\mathrm{Ng}$ et al (2002) who found decreased levels of antithrombin III and protein $\mathrm{C}$ in hemodilution by normal saline. Antithrombin III is the most potent inhibitors that inhibit the intrinsic factor IXa, Xa, Xia and XIIa, while protein C has functions in the degradation of factor VIII, which enables a decrease in antithrombin III and protein $\mathrm{C}$ since the use of crystalloid is still going to be a factor in the coagulation process.

\section{CONCLUSION}

HES 200 in a maximum dose of $20 \mathrm{ml} / \mathrm{kg}$ is safe for use in elective surgery patients who experience bleeding of averagely $15 \%$ EBV.

\section{REFERENCES}

Boldt J (2008). Fluid choice for resuscitation in trauma. International Trauma Care 18, 57-65

Casari C, Lenting PJ, Wohner N, Christophe OD, Denis CV (2013). Clearance of von Willebrand factor. J Thromb Haemost 11 Suppl 1, 202-211

Collis RE, Collins PW, Gutteridge CN, Kaul A, Newland AC, Williams DM, Webb AR (1994). The effect of hydroxyethyl starch and other plasma volume substitutes on endothelial cell activation; an in vitro study. Intensive Care Med 20, 37-41

de Jonge E, Levi M, Büller HR, Berends F, Kesecioglu J (2001). Decreased circulating levels of von Willebrand factor after intravenous administration of a rapidly degradable hydroxyethyl starch (HES 200/0.5/6) in healthy human subjects. Intensive Care Med 27, 1825-1829

Fenger-Eriksen C, Jensen TM, Kristensen BS, Jensen KM, Tønnesen E, Ingerslev J, Sørensen B (2009). Fibrinogen substitution improves whole blood clot firmness after dilution with hydroxyethyl starch in bleeding patients undergoing radical cystectomy: a randomized, placebo-controlled clinical trial. J Thromb Haemost 7, 795-802

Gabali A, Jazearly T, Ramchandren R, Bluth $\mathrm{MH}$ (2014). Applications of coagulation testing and methodology in the trauma patient. Research and Reviews: Journal of Medical and Health Sciences 3, 14

Gan TJ (2011). Colloid or crystalloid: any differences in outcomes? IARS Review Course Lectures, 7-12

Guidet B, Martinet O, Boulain T, Philippart F, Poussel JF, Maizel J, Forceville X, Feissel M, Hasselmann M, Heininger A, Van Aken H (2012). Assessment of hemodynamic efficacy and safety of $6 \%$ hydroxyethylstarch $130 / 0.4$ vs. $0.9 \% \quad \mathrm{NaCl}$ fluid replacement in patients with severe sepsis: the CRYSTMAS study. Crit Care 16, R94

Innerhofer P, Fries D, Margreiter J, Klingler A, Kühbacher G, Wachter B, Oswald E, Salner E, Frischhut B, Schobersberger W (2002). The effects of perioperatively administered colloids and crystalloids on primary platelet-mediated hemostasis and clot formation. Anesth Analg 95, 858-865 
Kamal AH, Tefferi A, Pruthi RK (2007). How to interpret and pursue an abnormal prothrombin time, activated partial thromboplastin time, and bleeding time in adults. Mayo Clin Proc 82, 864-873

Kozek-Langenecker SA, Jungheinrich C, Sauermann W, Van der Linden P (2008). The effects of hydroxyethyl starch 130/0.4 (6\%) on blood loss and use of blood products in major surgery: a pooled analysis of randomized clinical trials. Anesth Analg 107, 382-390

Langeron O, Doelberg M, Ang ET, Bonnet F, Capdevila X, Coriat P (2001). Voluven, a lower substituted novel hydroxyethyl starch (HES 130/0.4), causes fewer effects on coagulation in major orthopedic surgery than HES 200/0.5. Anesth Analg 92, 855-862

Lenting PJ, Christophe OD, Denis CV (2015). von Willebrand factor biosynthesis, secretion, and clearance: connecting the far ends. Blood 125, 20192028

Mills GH (2007). Hydroxyethyl starch: does our choice of colloid prevent or add to renal impairment? $\mathrm{Br} \mathrm{J}$ Anaesth 98, 157-159

Muralidhar K, Garg R, Mohanty S, Banakal S (2010). Influence of colloid infusion on coagulation during off-pump coronary artery bypass grafting. Indian $\mathbf{J}$ Anaesth 54, 147-153

Myburgh JA and Mythen MG (2013). Resuscitation fluids. The New England Journal of Medicine 369, 1243-1251
$\mathrm{Ng}$ KF, Lam CC, Chan LC (2002). In vivo effect of haemodilution with saline on coagulation: a randomized controlled trial. Br J Anaesth 88, 475-480

Peyvandi F, Garagiola I, Baronciani L (2011). Role of von Willebrand factor in the haemostasis. Blood Transfus 9, s3-s8

Reininger AJ (2008). Function of von Willebrand factor in haemostasis and thrombosis. Haemophilia 14, 1126

Rittoo D, Gosling P, Simms MH, Smith SR, Vohra RK (2005). The effects of hydroxyethyl starch compared with gelofusine on activated endothelium and the systemic inflammatory response following aortic aneurysm repair. Eur J Vasc Endovasc Surg 30, 520524

Ruttmann TG, James MF, Finlayson J (2002). Effects on coagulation of intravenous crystalloid or colloid in patients undergoing peripheral vascular surgery. Br J Anaesth 89, 226-230

Sadler JE (2009). Low von Willebrand factor: sometimes a risk factor and sometimes a disease. Hematology Am Soc Hematol Educ Program, 106112

Wilson DD (2007). McGraw-Hill Manual of Laboratory and Diagnostic Tests 1st Edition, New York, McGraw-Hill Education 